Our Nature
Journal homepage: http://nepjol.info/index.php/ON

\title{
A report of Siwalik forest around Letang Raja-Rani wetland, Morang, eastern Nepal
}

\author{
Momita Chettry ${ }^{1}$, Rijan Ojha ${ }^{1,2 *}$ and Bhabindra Niroula ${ }^{1}$ \\ ${ }^{1}$ Department of Botany, Post Graduate Campus, Tribhuvan University, Biratnagar, Nepal \\ ${ }^{2}$ Biodiversity Research and Conservation Society, Kathmandu, Nepal \\ *E-mail: reasonojha55@gmail.com
}

\begin{abstract}
Species composition, phytosociological status and soil characteristics of Siwalik forest occurring around Raja-Rani wetland, Letang municipality, eastern Nepal was studied. A total of 47 tree species belonging to 40 genera and 26 families were reported. Dominant and co-dominant trees were Shorea robusta (IVI=133.4) and Schima wallichii (IVI=70.6), respectively. In the forest total tree density, basal cover area, seedling density, fallen dead density and dead standing density were 378.4 trees $\mathrm{ha}^{-1}, 163.7 \mathrm{~m}^{2} \mathrm{ha}^{-1}, 105250$ individual $\mathrm{ha}^{-1}, 4$ trees $\mathrm{ha}^{-1}$ and 1.6 trees $\mathrm{ha}^{-1}$, respectively. Irregular girth class distribution and high stump density (136.8 tree ha$\left.{ }^{1}\right)$ denote disturbance. Soil physicochemical characteristics were: acidic soil ( $\mathrm{pH} 4.8$ ), moisture (12.5\%), water holding capacity $(50.05 \%)$, bulk density $\left(1.17 \mathrm{~g} \mathrm{~cm}^{-3}\right)$, porosity $(0.55 \%)$, humus $(8.6 \%)$, organic carbon $(0.52 \%)$, nitrogen $(0.1 \%)$, phosphorus (33 $\left.\mathrm{kg} \mathrm{ha} \mathrm{ha}^{-1}\right)$, and potassium $\left(300 \mathrm{~kg} \mathrm{ha} \mathrm{ha}^{-1}\right)$. Regulating human encroachment to ensure natural regeneration of species to maintain the viability of the Letang Raja-Rani wetland site and integrity of the local ecosystem is strongly recommended.
\end{abstract}

Key words: Girth class, phytosociology, Shorea robusta, soil characteristics

DOI: https://doi.org/10.3126/on.v19.i1.41232

Manuscript details: Received: 12.06.2021 / Accepted: 03.11.2021

Citation: Chettry, M., R. Ojha and B. Niroula 2021. A report of Siwalik forest around Letang Raja-Rani wetland, Morang, eastern Nepal. Our Nature 19(1): 37-45. DOI: https://doi.org/10.3126/on.v19.i1.41232

Copyright: (C) Chettry et al., 2021. Creative Commons Attribution - Non Commercial 4.0 International License.

\section{Introduction}

Forests exhibit a significant proportion of global biodiversity (Naidu and Kumar, 2016). Forest itself being versatile and rich natural resources has uplifted a wide range of economic, social, environmental and cultural benefits and services. The analysis of structural and functional parameters of the plant community is fundamental for the conservation of natural areas (Zhang et al., 2013). Continuous loss of forest area is a major threat to biodiversity. In the past eight decades (1930-2014) Nepal lost $37318 \mathrm{~km}^{2}$ $(48.6 \%)$ of its primary forest cover but net deforestation for the recent period (2005-2014) indicates $0.01 \%$ forest loss per year (Reddy et al., 2018).

The tropical forest of eastern Nepal holds significant importance because it falls under the Eastern Himalayas Biodiversity hotspot. The tropical region of Nepal bears gradients of Terai plain and Siwalik hills (Chure). Siwalik occupies $12.7 \%$ of the total land and contributes to $23.09 \%$ of the forest cover of the country (LRMP, 1986; Uddin et al., 2015). They are the youngest and the southernmost mountain chain of the Himalayan system (Hagen, 1998) having tertiary unconsolidated and highly erodible fluviatile sediments (Carson, 1985). Due to steep slopes with erodible and poor soil, the area is 


\section{Chhetry, Ojha and Niroula / Our Nature | December 2021 | 19 (1): $37-45$}

unsuitable for agriculture and settlements. In eastern Nepal, Siwalik has widespread human settlements and associated disturbances. Siwalik Forest decreased by $23 \%\left(150 \mathrm{~km}^{2}\right)$ in less than 35 years in eastern Nepal (Bhuju et al., 2007).

Few studies are confined to the Siwalik range of eastern Nepal (Nirola and Jha, 2011; Bhattrai and Mandal, 2016). Although a diverse climate and vegetation exist on the Siwalik range, the biodiversity is poorly understood. Furthermore, occurrence of moist and humid environment of the forest around the Raja-Rani wetland supports unique diversity, from tropical to temperate climate. In this context, the present study aims to provide baseline information about forest species composition, phytosociology, leaf litter mass and soil properties of the area.

\section{Materials and methods}

\section{Study area}

The study was conducted during 2017 to 2018 in Raja-Rani community forest area (1700 ha, $26^{\circ} 44.9^{\prime 2} 22^{\prime \prime} \mathrm{N}$ latitude, $87^{\circ} 28.9^{\prime} 10^{\prime \prime}$ E longitude, $470 \mathrm{~m}$ altitude) situated in Letang Municipality1, Morang district, Eastern Nepal (Fig. 1). The climate of the study has three distinct seasons, hot and humid summer; rain rich monsoon; cold and dry winters. In this region the average annual

\section{Vegetation and litter mass analysis}

Quadrants of $25 \times 25 \mathrm{~m}^{2}$ were randomly established for the study of trees (large, small and poles). Similarly, five quadrates of $5 \times 5 \mathrm{~m}^{2}$ and $2 \times 2 \mathrm{~m}^{2}$ were used for sapling and seedling respectively. Diameters of more than $15 \mathrm{~cm}$ were large trees, between 10 to $15 \mathrm{~cm}$ small trees, between 5 to $10 \mathrm{~cm}$ poles, between 2 to $5 \mathrm{~cm}$ sapling and diameter below $2 \mathrm{~cm}$ were recorded as seedlings. A total of nine girth classes (10 to $510 \mathrm{~cm}$ with an interval of 30) were established, dead stump, standing dead and fallen trees was recorded. Herbarium of trees were prepared and brought to the Department of Botany, Post Graduate Campus, Tribhuvan University, Biratnagar for identification. Density, relative density, frequency, relative frequency, basal area and relative basal area and IVI were determined as Mishra (1968) and Zobel et al. (1987). Species minimum temperature ranges from $12-19^{\circ} \mathrm{C}$, the average annual maximum temperature ranges from $22-30^{\circ} \mathrm{C}$ and annual rainfall ranges from 1138-2671 mm (DFRS, 2014).

The forest lies around the Raja-Rani wetland with rich biological diversity. It is a religious and historic place of the Dhimal tribe and an important tourist destination of eastern Nepal. Local community depends on the area for collection of fodder, fuel wood, wild foods, medicinal plants and livestock grazing.

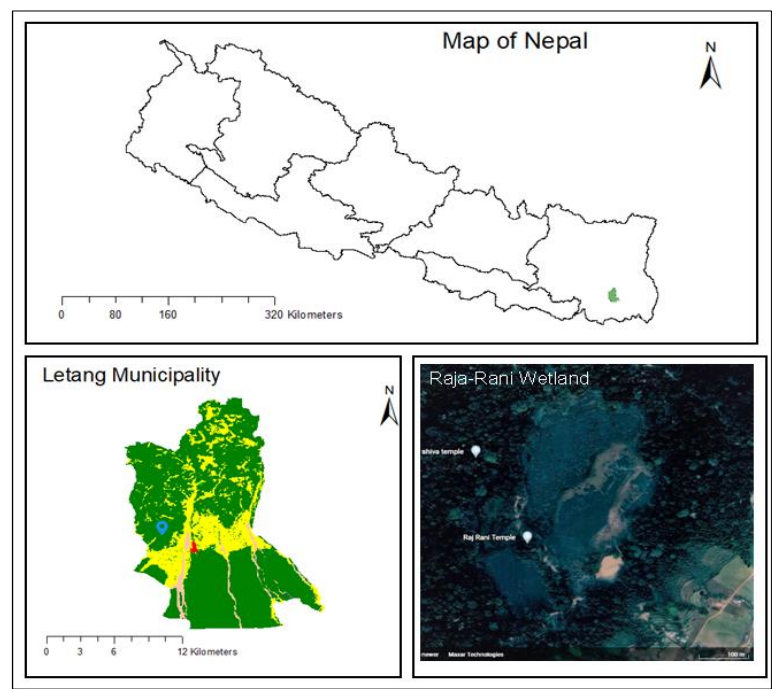

Figure 1. Map of the study area.

diversity parameters such as Equitability (Evenness) (Pielou, 1966), Simpson index (Simpson, 1949), Shannon-Wiener index (Shannon and Weaver, 1963), and species richness (Margalef, 1958) were calculated. Leaf litter mass was measured seasonally from the litter trap $\left(1 \times 1 \mathrm{~m}^{2}\right)$ fixed on the forest floor in each sampling plot from April 2017 to March 2018.

\section{Soil analysis}

Soil samples were collected from randomly placed pits of $10 \times 10 \times 15 \mathrm{~cm}^{3}$ depth. Large pieces of plant materials, fine roots and pebbles were removed carefully from each sample. Each sample was mixed and pooled as one replicate. Soil moisture, water holding capacity, organic matter, soil texture, porosity, bulk density, carbon, $\mathrm{pH}$, total nitrogen, total phosphorus and potassium were analyzed using standard methods (Table 1). 
Table 1. Method of soil analysis used in the study.

\begin{tabular}{cllll}
\hline S.N. & Soil property & Analysis method & Unit & References \\
\hline 1 & Soil moisture & Oven drying method & $\%$ & (Piper, 1966) \\
2 & Water holding capacity & - & $\%$ & (Zobel et al., 1987) \\
3 & Humus & - & $\%$ & (Zobel et al., 1987) \\
4 & Soil texture & Sieve method & $\%$ & (Piper, 1966) \\
5 & Porosity & - & $\%$ & (Blake, 1965) \\
6 & Bulk density & Core sampling method & $\mathrm{g} \mathrm{cm}^{-3}$ & (Blake, 1965) \\
7 & Soil Organic Carbon & Titrimetric method & $\%$ & (Kalembasa and Jenkinson, 1973) \\
8 & Organic Matter & Titrimetric method & $\%$ & (Kalembasa and Jenkinson, 1973) \\
9 & pH & pH meter & & (Piper, 1966) \\
10 & Total nitrogen & Micro Kjeldahl Method & $\%$ & (Bremner, 1960) \\
11 & Phosphorus & Olsen's method & $\mathrm{Kg} \mathrm{ha}^{-1}$ & (Jackson, 1958) \\
12 & Potassium & Flame photometer method Kg ha & (Knudsen et al., 1983) \\
\hline
\end{tabular}

\section{Results}

A total of 47 tree species belonging to 26 families and 40 genera are recorded from the area (Table 2). Euphorbiaceae was the largest family with 5 species followed by Fabaceae (4), Combretaceae, Myrtaceae, Rubiaceae and Theaceae (3 species in each). Apocynaceae, Fabaceae, Meliaceae, Rosaceae had 2 species in each and the rest of the families had single species in each.

Shorea robusta was the dominant species (IVI=133.4); Schima wallichii (IVI 70.57) was codominant, followed by Croton roxburghii (IVI 36.56) in the forest (Table 3). The tree density and basal area were 378.38 trees $\mathrm{ha}^{-1}, 163.66 \mathrm{~m}^{2} \mathrm{ha}^{-1}$, respectively (Table 4 ). The higher dead stump denotes (136.8 stump ha- $\left.{ }^{-1}\right)$ denotes the disturbance.
The forest has more seedlings than saplings and poles (Fig.2). There was a higher density of young tree species in the study area. The relationship between girth class distribution and density of total trees, S. robusta and S. wallichii of Siwalik forest around Letang Raja-Rani wetland, Eastern Nepal is given in figure 3.

The summer season had maximum litter mass $\left(27025 \mathrm{~kg} \mathrm{ha}^{-1}\right)$ followed by the winter season $\left(9000 \mathrm{~kg} \mathrm{ha}^{-1}\right)$ and least in the rainy season $(1705$ $\left.\mathrm{kg} \mathrm{ha}^{-1}\right)$.

The soil was acidic, rich in organic matter and clayey (Table 5).

Table 2. Enumeration of Siwalik forest trees around Letang Raja-Rani wetland, eastern Nepal.

\begin{tabular}{clll}
\hline S.N. Family & Species & Local Name \\
\hline 1 & Alangiaceae & Alangium salvifolium (L.f) & Asare \\
2 & Anacardiaceae & Rhus succedanea L. & Bhalayo \\
3 & Apocynaceae & Alstonia scholaris (L.) Benth. & Chhativan \\
4 & Apocynaceae & Holarrhena pubenscens (Buch-Ham.) Wall.ex DC. & Aulekhirro \\
5 & Arecaceae & Caryota urens L. & Rang vang \\
6 & Burseraceae & Garuga pinnata Roxb. & Dabdabe \\
7 & Combretaceae & Terminalia alata Heyneex. Roth & Saaj \\
8 & Combretaceae & T. chebula Retz. & Harro \\
9 & Combretaceae & T. bellirica (Gaerth.) Roxb. & Barro \\
10 & Corditaceae & Ehretia acuminate R.Br. & Dhatrunga \\
11 & Dipterocarpaceae & Shorea robusta Gaertn. & Sal/ Sakhuwa \\
12 & Ebenaceae & Diospyros tomentosa Roxb. & Kalikath \\
13 & Elaeagnaceae & Elaeagnus infundibularis Momiy. & Guyelo \\
14 & Euphorbiaceae & Croton roxburghii N.P.Balakr. & Aaulea
\end{tabular}




\begin{tabular}{|c|c|c|c|}
\hline 15 & Euphorbiaceae & Mallotus philippensis (Lam.) Mull.Arg. & Sindure \\
\hline 16 & Euphorbiaceae & Trewia nudiflora (L.) & Pithari \\
\hline 17 & Euphorbiaceae & Macaranga indica Wight & Malata \\
\hline 18 & Euphorbiaceae & Phyllanthus emblica L. & Ban amala \\
\hline 19 & Fabaceae & Albizia julibrissin (Durazz) & Ratosiris \\
\hline 20 & Fabaceae & A. lebbeck (L.) Benth & Padkesiris \\
\hline 21 & Fabaceae & Albizia sp. & Laharesiris \\
\hline 22 & Fabaceae & Cassia fistula $\mathrm{L}$. & Rajbrikshya \\
\hline 23 & Fagaceae & Castanopsis indica (Roxb.) & Dhalnekatush \\
\hline 24 & Fagaceae & C. tribuloides (Sm.) A.DC. & Musurekatush \\
\hline 25 & Lauraceae & Litsea monopetala (Roxb.) & Kutmero \\
\hline 26 & Lecythidaceae & Careya arborea Roxb. & Kumbhi \\
\hline 27 & Lythraceae & Lagerstroemia parviflora Roxb. & Botdhayero \\
\hline 28 & Magnoliaceae & Michelia doltsopa (L.) Bill.explore & Chaap \\
\hline 29 & Malvaceae & Sterculia villosa (Roxb.) & Odane/Odal \\
\hline 30 & Meliaceae & Trichilia connaroides (Wight\&Am.) Bentv. & Akhataruwa \\
\hline 31 & Meliaceae & Toona serrata (Royle) M.Roem. & Tooni \\
\hline 32 & Myristicaceae & Knema tenuinervia W.J.de Wilde & Ban suntala \\
\hline 33 & Myrtaceae & Cleistocalyx operculatus (Roxb.) & Kyamuna \\
\hline 34 & Myrtaceae & Syzygium cumini (L.) Skeels & Jamun \\
\hline 35 & Myrtaceae & S. nervosum (DC) & Fadir \\
\hline 36 & Rosaceae & Prunus sp. & - \\
\hline 37 & Rosaceae & Docynia indica (Wall.) Decne & Mehel \\
\hline 38 & Rubiaceae & Adina cordifolia (wild.ex. Roxb) Benth. \& Hook. & Karam \\
\hline 39 & Rubiaceae & Cephalanthus tetrandra (Roxb). & Paanisimali \\
\hline 40 & Rubiaceae & Hymenopogon parasiticus Wall. & Hansraj \\
\hline 41 & Rutaceae & Zanthoxylum armatum (DC., Prodr.) & Timur \\
\hline 42 & Sapindaceae & Acer oblongum Wall.ex.DC. & Phirphire \\
\hline 43 & Sterculiaceae & Pterospermum acerifolium (L.) Willd. & Hatti Pailey \\
\hline 44 & Sonneratiaceae & Duabanga grandiflora (Roxb.ex.DC.) Walpers. & Lampate \\
\hline 45 & Theaceae & Schima wallichii (DC.) Korth. & Uttish \\
\hline 46 & Theaceae & Unidentified sp.1 & Chari dane \\
\hline 47 & Theaceae & Unidentified sp.2 & Tilke \\
\hline
\end{tabular}

Table 3. Density, frequency, basal area and importance value index (IVI) Siwalik forest trees around Letang Raja-Rani wetland, eastern Nepal. (Mean \pm S.E.)

\begin{tabular}{|c|c|c|c|c|c|}
\hline S.N. & Species & Density (tree ha') & Frequency $(\%)$ & Basal area $\left(\mathrm{m}^{2} \mathbf{h a}\right)^{1}$ & IVI \\
\hline 1 & Acer oblongum & $0.8 \pm 0.4$ & $5 \pm 1$ & $0.007 \pm 0.04$ & $0.94 \pm 0.4$ \\
\hline 2 & Adina cordifolia & $4.8 \pm 0.98$ & $15 \pm 1.73$ & $0.123 \pm 0.16$ & $3.67 \pm 0.8$ \\
\hline 3 & Alangiu msalvifolium & $1.6 \pm 0.5$ & $10 \pm 1.41$ & $0.013 \pm 0.05$ & $2.14 \pm 0.6$ \\
\hline 4 & Albizia julibrissin & $1.6 \pm 0.5$ & $10 \pm 1.41$ & $0.0014 \pm 0.017$ & $2.13 \pm 0.6$ \\
\hline 5 & Albizia lebbeck & $0.8 \pm 0.4$ & $5 \pm 1$ & $0.001 \pm 0.014$ & $1.5 \pm 0.5$ \\
\hline 6 & Albizia sp. (Laharesiris) & $0.8 \pm 0.4$ & $5 \pm 1$ & $0.0007 \pm 0.01$ & $1.42 \pm 0.5$ \\
\hline 7 & Alstonia scholaris & $0.8 \pm 0.4$ & $5 \pm 1$ & $0.06 \pm 0.11$ & $0.76 \pm 0.4$ \\
\hline 8 & Careya arborea & $0.8 \pm 0.4$ & $5 \pm 1$ & $0.0098 \pm 0.04$ & $1.43 \pm 0.5$ \\
\hline 9 & Cassia fistula & $1.6 \pm 0.5$ & $5 \pm 1$ & $0.015 \pm 0.05$ & $0.88 \pm 0.4$ \\
\hline 10 & Castanopsis indica & $0.8 \pm 0.4$ & $5 \pm 1$ & $0.004 \pm 0.03$ & $0.71 \pm 0.4$ \\
\hline 11 & Cleistocalyx operculatus & $0.8 \pm 0.4$ & $5 \pm 1$ & $0.003 \pm 0.02$ & $0.71 \pm 0.4$ \\
\hline 12 & Croton roxburghii & $14.4 \pm 1.7$ & $40 \pm 2.83$ & $0.34 \pm 0.26$ & $36.56 \pm 2.7$ \\
\hline 13 & Duabanga grandiflora & $1.6 \pm 0.5$ & $10 \pm 1.41$ & $0.006 \pm 0.03$ & $2.44 \pm 0.7$ \\
\hline 14 & Diospyros tomentosa & $3.2 \pm 0.8$ & $15 \pm 1.73$ & $0.012 \pm 0.05$ & $4.21 \pm 0.9$ \\
\hline 15 & Docynia indica & $0.8 \pm 0.4$ & $5 \pm 1$ & $0.0008 \pm 0.01$ & $0.71 \pm 0.4$ \\
\hline 16 & Elaeagnus infundibularis & $0.8 \pm 0.4$ & $5 \pm 1$ & $0.006 \pm 0.034$ & $0.94 \pm 0.4$ \\
\hline 17 & Garuga pinnata & $0.8 \pm 0.4$ & $5 \pm 1$ & $0.007 \pm 0.04$ & $0.71 \pm 0.4$ \\
\hline
\end{tabular}


Chhetry, Ojha and Niroula / Our Nature | December 2021| 19 (1): 37-45

\begin{tabular}{|c|c|c|c|c|c|}
\hline 18 & Holarrhena pubescens & $3.2 \pm 0.8$ & $15 \pm 1.73$ & $0.17 \pm 0.18$ & $2.53 \pm 0.7$ \\
\hline 19 & Hymenopogon parasiticus & $7.2 \pm 1.7$ & $10 \pm 1$ & $0.4013 \pm 0.28$ & $2.96 \pm 0.7$ \\
\hline 20 & Knema tenuinervia & $0.8 \pm 0.4$ & $5 \pm 1$ & $0.001 \pm 0.01$ & $1.42 \pm 0.5$ \\
\hline 21 & Lagerstroemia parviflora & $8 \pm 1.3$ & $35 \pm 2.65$ & $0.62 \pm 0.35$ & $9.58 \pm 1.4$ \\
\hline 22 & Litsea monopetala & $0.8 \pm 0.4$ & $5 \pm 1$ & $0.002 \pm 0.02$ & $0.71 \pm 0.4$ \\
\hline 23 & Macaranga indica & $0.8 \pm 0.4$ & $5 \pm 1$ & $0.0007 \pm 0.01$ & $1.42 \pm 0.5$ \\
\hline 24 & Mallotus philippensis & $0.8 \pm 0.4$ & $5 \pm 1$ & $0.003 \pm 0.02$ & $1.50 \pm 0.5$ \\
\hline 25 & Michelia doltsopa & $0.8 \pm 0.4$ & $5 \pm 1$ & $0.04 \pm 0.09$ & $1.59 \pm 0.6$ \\
\hline 26 & Phyllanthus emblica & $0.8 \pm 0.4$ & $5 \pm 1$ & $0.005 \pm 0.03$ & $1.56 \pm 0.6$ \\
\hline 27 & Prunus sp. & $0.8 \pm 0.4$ & $5 \pm 1$ & $0.001 \pm 0.01$ & $1.56 \pm 0.6$ \\
\hline 28 & Pterospermum acerifolium & $2.4 \pm 0.7$ & $10 \pm 1.41$ & $0.008 \pm 0.04$ & $2.03 \pm 0.6$ \\
\hline 29 & Rhus succedanea & $1.6 \pm 0.5$ & $5 \pm 1$ & $0.002 \pm 0.02$ & $1.70 \pm 0.6$ \\
\hline 30 & Schima wallichii & $72.18 \pm 3.8$ & $90 \pm 4.24$ & $29.26 \pm 2.42$ & $70.57 \pm 3.7$ \\
\hline 31 & Shorea robusta & $135.2 \pm 5.2$ & $100 \pm 4.47$ & $131.07 \pm 5.12$ & $133.4 \pm 5.2$ \\
\hline 32 & Sterculia villosa & $21.6 \pm 2.1$ & $45 \pm 3$ & $0.64 \pm 0.36$ & $11.65 \pm 1.5$ \\
\hline 33 & Syzygium cumini & $1.6 \pm 0.5$ & $10 \pm 1.41$ & $0.02 \pm 0.06$ & $1.66 \pm 0.6$ \\
\hline 34 & Syzygium nervosum & $0.8 \pm 0.4$ & $5 \pm 1$ & $0.093 \pm 0.14$ & $0.8 \pm 0.4$ \\
\hline 35 & Terminalia alata & $1.6 \pm 0.5$ & $10 \pm 1.41$ & $0.16 \pm 0.18$ & $1.57 \pm 0.6$ \\
\hline 36 & Terminalia bellirica & $0.8 \pm 0.4$ & $5 \pm 1$ & $0.0045 \pm 0.03$ & $0.94 \pm 0.4$ \\
\hline 37 & Terminalia chebula & $1.6 \pm 0.5$ & $5 \pm 1$ & $0.003 \pm 0.02$ & $0.87 \pm 0.4$ \\
\hline 38 & Toona serrata & $0.8 \pm 0.4$ & $5 \pm 1$ & $0.0007 \pm 0.01$ & $1.42 \pm 0.5$ \\
\hline 39 & Trewia nudiflora & $5.6 \pm 1.06$ & $15 \pm 1.73$ & $0.0098 \pm 0.04$ & $3.31 \pm 0.8$ \\
\hline 40 & Trichilia connaroides & $0.8 \pm 0.4$ & $5 \pm 1$ & $0.004 \pm 0.03$ & $0.71 \pm 0.4$ \\
\hline 41 & Unidentified sp. 1 & $14.4 \pm 1.7$ & $35 \pm 2.65$ & $0.59 \pm 0.34$ & $7.79 \pm 1.2$ \\
\hline 42 & Unidentified sp.2 & $0.8 \pm 0.4$ & $5 \pm 1$ & $0.010 \pm 0.04$ & $0.94 \pm 0.4$ \\
\hline \multirow[t]{2}{*}{43} & Zanthoxylum armatum & $0.8 \pm 0.4$ & $5 \pm 1$ & $0.0003 \pm 0.008$ & $1.42 \pm 0.5$ \\
\hline & Total & $323.38 \pm 8.04$ & $605 \pm 11$ & $163.72 \pm 5.7$ & $300 \pm 7.7$ \\
\hline
\end{tabular}

Table 4. Status of forest stand around Raja-Rani wetland, eastern Nepal.

\begin{tabular}{|c|c|}
\hline Parameter & Status \\
\hline Density $\left(\right.$ Trees ha-1 ${ }^{-1}$ & 378.38 \\
\hline Basal area $\left(\mathrm{m}^{2} \mathrm{ha}^{-1}\right)$ & 163.66 \\
\hline Diversity index H' & 1.65 \\
\hline Concentration of dominance & 0.33 \\
\hline Species richness & 2.65 \\
\hline Evenness & 0.59 \\
\hline Standing dead $\left(\right.$ Trees ha $\left.{ }^{-1}\right)$ & 1.6 \\
\hline Fallen tree $($ Trees ha-1) & 4.0 \\
\hline Rotten trees $($ Trees ha-1 $)$ & 0.8 \\
\hline Dead stump (Trees ha' $\left.{ }^{-1}\right)$ & 136.8 \\
\hline
\end{tabular}

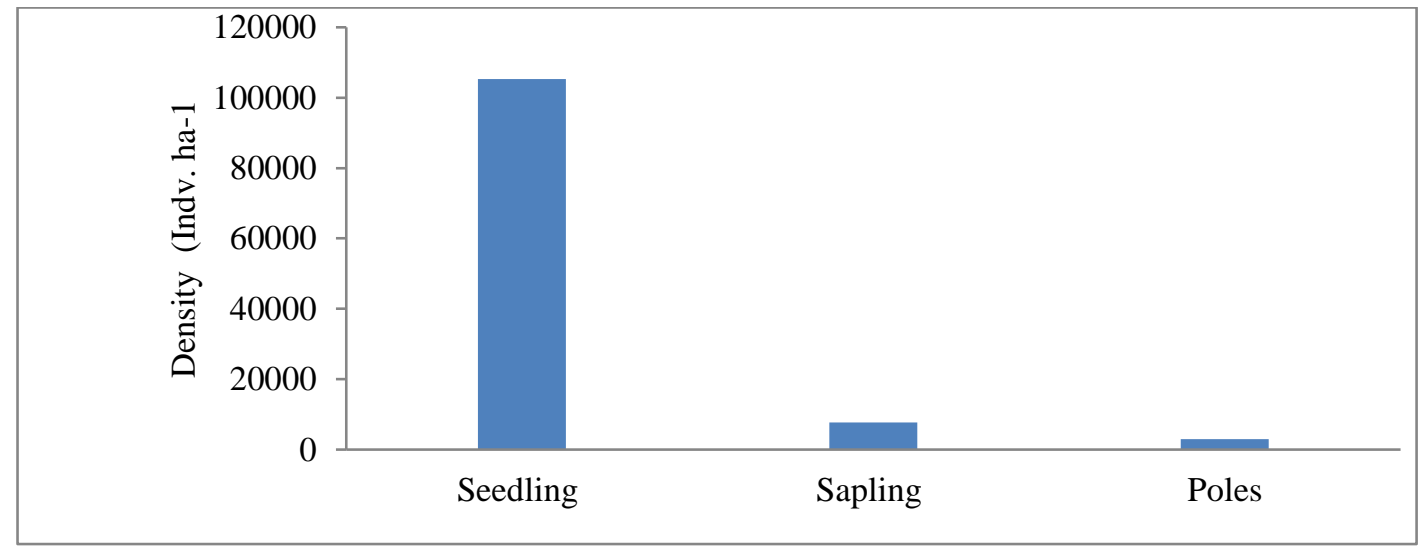

Figure 2. Occurrence of seedlings, saplings and poles in the forest of Raja-Rani wetland. 


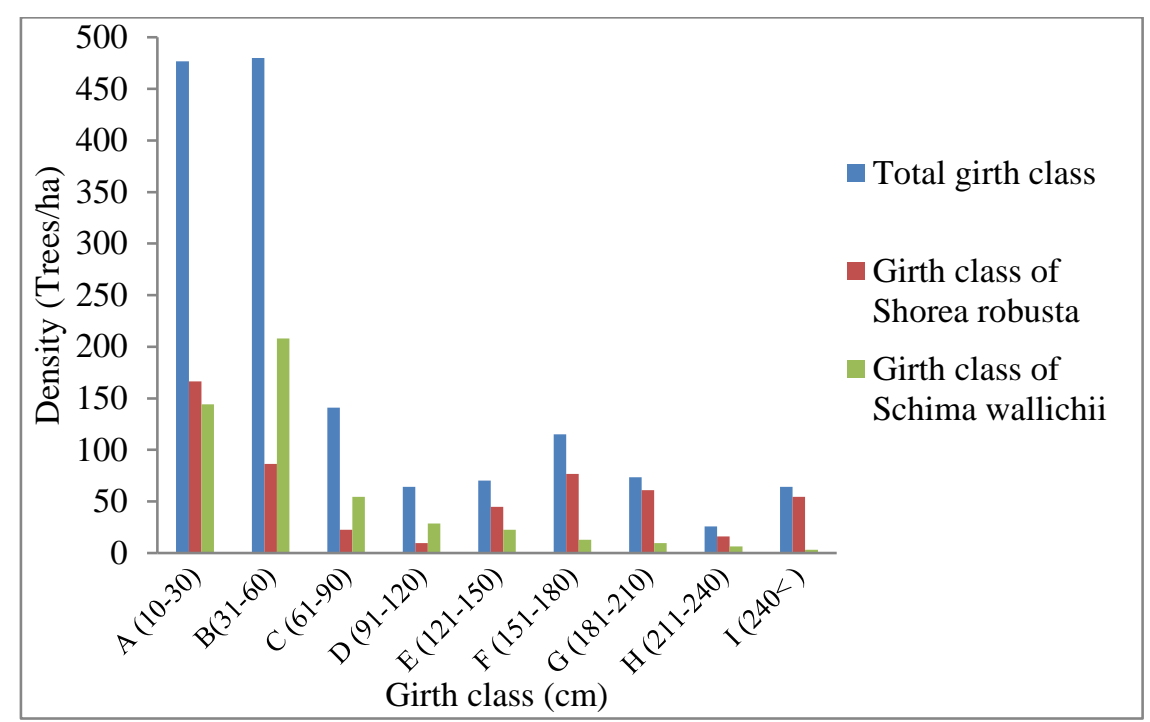

Figure 3. The relationship between girth class distribution and density of total trees, Shorea robusta and Schima wallichii of Siwalik forest around Letang Raja-Rani wetland, eastern Nepal.

Table 5. Soil physicochemical characteristics ( $0-15 \mathrm{~cm}$ depth) from Raja-Rani forest (Mean \pm Standard Error).

\begin{tabular}{cll}
\hline S.N. & Soil properties & Mean \pm SE \\
\hline 1 & Soil Moisture $(\%)$ & $12.5 \pm 0.9$ \\
2 & pH & $4.8 \pm 0.17$ \\
3 & BD $\left(\mathrm{g} \mathrm{cm}^{-3}\right)$ & $1.17 \pm 0.07$ \\
4 & Porosity & $0.55 \pm 0.01$ \\
5 & WHC $(\%)$ & $50.05 \pm 1.43$ \\
6 & Soil Texture & \\
& Sand (\%) & $15.67 \pm 2.71$ \\
& Silt $(\%)$ & $23.57 \pm 1.4$ \\
& Clay (\%) & $60.8 \pm 2.54$ \\
7 & Humus (\%) & $8.64 \pm 2.85$ \\
8 & Soil Organic Carbon $(\%)$ & $0.52 \pm 0.09$ \\
9 & Organic matter (\%) & $0.89 \pm 0.12$ \\
10 & Total Nitrogen (\%) & $0.13 \pm 0.02$ \\
11 & Phosphorus $\left(\mathrm{Kg} \mathrm{ha}^{-1}\right)$ & $33 \pm 3.33$ \\
12 & Potassium $\left(\mathrm{Kg} \mathrm{ha}^{-1}\right)$ & $300 \pm 9.38$ \\
\hline
\end{tabular}

\section{Discussion}

\section{Soil characteristics}

The humus rich $(8.64 \%)$, clayey soil $(60.8 \%)$ had acidic $\mathrm{pH}(4.8)$ in the forest. More acidic $\mathrm{pH}(4.2)$ was reported in pure Shorea forest of Udaypur district (Paudel and Sah, 2003); the soil pH was between 5.6 and 6.2 in Chure range of Ilam district (Nirola and Jha, 2011). Comparative study of bulk density, $\mathrm{pH}$, water holding capacity (WHC), organic matter and soil texture in the teraisal forest,
Jhapa; tropical moist forest Sunsari and tropical hill sal forest, Ilam is presented in figure 4 .

\section{Forest status}

In S. robusta dominated forest, Bhattarai (2008) reported similar IVI (130) in Namuna community forest Salbari, Jhapa; lower IVI (60.95-64.61) in churia range of Ilam (Nirola and Jha, 2011); higher IVI (183) in Tropical moist sal forest, Sunsari (Mandal, 1999). In the Namuna community forest Salbari, Jhapa higher tree density (1790 tree ha $\left.{ }^{-1}\right)$ and lower basal area $\left(31.45 \mathrm{~m}^{2} \mathrm{ha}^{-1}\right)$ were observed 
than the present study. Gautam and Mandal (2018) reported higher species richness (9.11), diversity index (3.08) and evenness (0.59) in the tropical moist forest of Sunsari. In the present study, a higher concentration of dominance $(0.33)$ is due to sharing of large proportions by a few species (Singh and Singh, 1991).

The Shannon-Wiener index of the tree species from the present study is compared with different forest stands of eastern Nepal (Table 6), which indicated that a similar diversity index of the forest stand was observed by Mandal (1999) in Tropical Plateau Sal forest but diversity index of the present study was lowest among them. The close canopy of the present forest stand may be the reason for the low diversity index.

A similar density of the sapling was recorded by Bhattarai (2008) in Namuna community forest Salbari, Jhapa. The highest number of seedlings also supports the properties of soil or litter. Minimum records of sapling and poles density of trees showed the impact of human encroachment. Further, irregular girth class distribution of tree, high stump density indicated the disturbance. The occurrence of dead stump marked the cutting of trees.

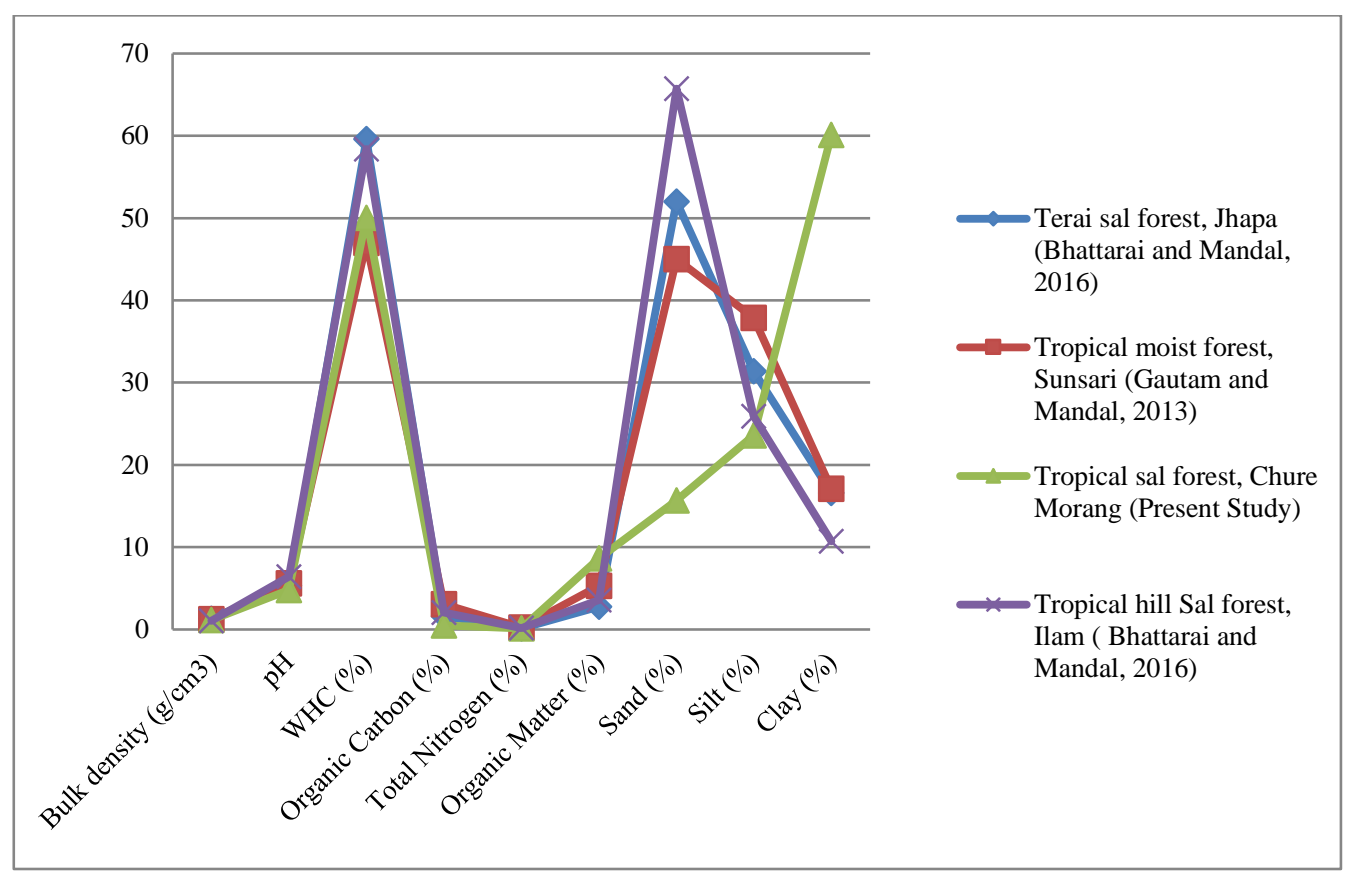

Figure 4. Comparative study of soil characteristics in different forest stand of eastern Nepal.

Table 6. Shannon-Wiener index $\left(\mathrm{H}^{\prime}\right)$ of tree species in different forest stands of eastern Nepal.

\begin{tabular}{lll}
\hline Forests and localities & H' index & References \\
\hline Tropical Plateau Sal forest & 1.66 & (Mandal, 1999) \\
Temperate Zone forest, TinjureMilke area & $2.4-2.61$ & (Koirala, 2004) \\
Tropical moist forest, Sunsari & 3.08 & (Gautam and Mandal, 2018) \\
Temperate Zone forest, Ilam & $3.22-3.68$ & (Chettri and Shrestha, 2019) \\
Tropical forest Siwalik hill, Eastern Nepal & 1.65 & Present study \\
\hline
\end{tabular}

\section{Conclusion}

The forest is under stress due to uncontrolled visitors, collection of forest products, livestock grazing, tree cutting and forest fire. Minimum diversity index $\left(\mathrm{H}^{-1}\right)$, species richness (d), high stump density and irregular girth class are threats. 
Regulating human encroachment to ensure natural regeneration of species to maintain the viability of Letang Raja-Rani wetland site and integrity of the local ecosystem is strongly recommended.

\section{Acknowledgments}

The authors are thankful to Prof. Dr. Sasinath Jha, Former Head, Department of Botany, Post Graduate Campus, Tribhuvan University, Biratnagar for kind support and encouragement to complete this work. We express sincere gratitude to Prof. Dr. Umesh Koirala, Head, Department of Botany, Post Graduate Campus, Tribhuvan University, Biratnagar to carry out the work. The authors are grateful to Akal Bahadur Magar, a local of Letang Raja-Rani village for his help during the fieldwork.

\section{References}

Bhattarai, K.P. 2008. Vegetation analysis of Namuna Community Forest of Salbari, Sanischare VDC in Jhapa District, Eastern Nepal. Journal of Natural History Museum 23:

12-15. https://doi.org/10.3126/jnhm.v23i0.1834

Bhattarai, K.P. and T.N. Mandal. 2016. Effect of altitudinal variation on the soil characteristics in Sal (Shorearobustagaertn.) forests of eastern Nepal. Our Nature 14(1):3038.https://doi.org/10.3126/on.v14i1.1643 8

Bhuju, D.R., P.B. Yonjon and B. Baidya. 2007. Landscape pattern and its change in the Churia of eastern Nepal. Ecoprint14: 6571.

https://doi.org/10.3126/eco.v14i0.4827

Blake, G.R. 1965. Bulk density. In: Methods of soil analysis. Part 1: Physical properties, Black CA (ed.). American Society of Agronomy: Madison, WI: 374-390. https://doi.org/10.2134/agronmonogr9.1.c 30

Bremner, J.M. 1960. Determination of nitrogen in soil by the Kjeldahl method. The Journal of Agricultural Science 55(1):11-33. https://doi.org/10.1017/S0021859600021 572

Carson, B. 1985. Erosion and sedimentation processes in the Nepal Himalaya.
ICIMOD Occasional Paper I. International Centre for Integrated Mountain Development, Kathmandu. https://doi.org/10.53055/ICIMOD.9

Chhetri, N.B.K. and K.K. Shrestha.2019. Floristic diversity and important value indices of tree species in lower Kanchenjunga Singhalila ridge Eastern Nepal. American Journal of Plant Sciences 10(1):248263.https://doi.org/10.4236/ajps.2019.101 019

DFRS2014. Churia forests of Nepal (2011-2013), Forest Resource Assessment Nepal Project, Department of Forest Research and Survey, Kathmandu, Nepal.

Gautam, T.P. and T.N. Mandal. 2018. Effect of disturbance on plant species diversity in moist tropical forest of eastern Nepal. Our Nature 16(1):1-7. https://doi.org/10.3126/on.v16i1.21558

Hagen, T. 1998. Nepal-the Kingdom of Himalaya ( $4^{\text {th }}$ ed.). Himal Books, Lalitpur, Nepal.

Jackson, M.L. 1958. Soil chemical analysis, Prentice Hall. Inc., Englewood Cliffs, New York.

Kalembasa, S.J. and D.S. Jenkinson. 1973. A comparative study of titrimetric and gravimetric methods for the determination of organic carbon in soil. Journal of Science, Food and Agriculture 24:1085-1090. https://doi.org/10.1002/jsfa.2740240910

Knudsen, D., G.A. Peterson and P.F. Pratt.1983. "Lithium, sodium, and potassium." Methods of Soil Analysis: Part 2 Chemical and Microbiological Properties 9:

225-246. https://doi.org/10.2134/agronmonogr9.2.2 ed.c13

Koirala, M. 2004. Vegetation composition and diversity of PiluwaMicro-watershed in Tinjure-Milke region, east Nepal. Himalayan journal of Sciences 2(3): 29-32. https://doi.org/10.3126/hjs.v2i3.227

LRMP, 1986. Land Utilization Report. Land Resources Mapping Project (LRMP), Kenting Earth Sciences Limited, Government of Nepal and Government of Canada. 
Mandal, T.N. 1999. Ecological analysis of recovery of landslide damaged Sal forest ecosystem in Nepal Himalaya. Banaras Hindu University, Varanasi, India. (Ph.D. thesis)

Margalef, R. 1958. Information theory in biology. General Systems Yearbook, 3: 36-71.

Mishra, R. 1968. Ecology, Work Book Oxford and IBH Publishing Co. New Delhi.

Naidu, M.T. and O.A. Kumar. 2016. Tree diversity, stand structure, and community composition of tropical forests in Eastern Ghats of Andhra Pradesh, India. Journal of Asia-Pacific Biodiversity9(3): 328334.https://doi.org/10.1016/j.japb.2016.0 3.019

Nirola, R. and P.K. Jha. 2011. Phytodiversity and soil study of Shiwalik Hills of Ilam, Nepal: an ecological perspective. Ecoprint: An International Journal of Ecology 18: 77-83. https://doi.org/10.3126/eco.v18i0.9414

Paudel, S. and J.P. Sah. 2003. Physiochemical characteristics of soil in tropical sal (Shorea robusta Gaertn.) forests in eastern Nepal. Himalayan Journal of Sciences 1(2): 107-110. https://doi.org/10.3126/hjs.v1i2.207

Pielou, E.C. 1966. The measurement of diversity in different types of biological collections. Journal of theoretical biology 13: 131-144. https://doi.org/10.1016/00225193(66)90013-0

Piper, C.S. 1966. Soil and Plant Analysis. Hans Publisher, Bombay.

Reddy, C.S., S.V.Pasha, K.V.Satish, K.R.L. Saranya, C.S. Jha and Y.K. Murthy. 2018. Quantifying nationwide land cover and historical changes in forests of Nepal (1930-2014): implications on forest fragmentation. Biodiversity and Conservation 27(1): 91 107.https://doi.org/10.1007/s10531-0171423-8

Shannon, C.E. and W. Weaver. 1963. The mathematical theory of communication. Champaign, IL, University of Illinois Press. pp.117

Simpson, E. H. 1949. Measurement of Diversity. Nature 163: 688-688. https://doi.org/10.1038/163688a0

Singh, L.J. and S. Singh. 1991. Species structure, dry matter dynamics and carbon flux of a dry tropical forest in India. Annals of Botany 68: 263-273. https://doi.org/10.1093/oxfordjournals.ao b.a088252

Uddin, K., H.L. Shrestha, M.S.R. Murthy, B. Bajracharya, B. Shrestha, H. Gilani, S. Pradhan, and B. Dangol. 2015. Development of 2010 national land cover database for the Nepal. Journal of environmental management 148: 8290.https://doi.org/10.1016/j.jenvman.201 4.07.047

Zobel, D.B., P.K. Jha, M.J. Behan and U.K.R. Yadav. 1987. A practical manual for ecology. Ratna Book Distributors, Kathmandu, Nepal, pp. 149.

Zhang, J. T., B. Xu and M. Li. 2013. Vegetation patterns and species diversity along elevational and disturbance gradients in the Baihua Mountain Reserve, Beijing, China.Mountain Research and Development 33(2): $\quad$ 170-178. http://dx.doi.org/10.1659/MRDJOURNAL-D-11-00042.1 